\title{
Chemical Composition, Antioxidant and Antimicrobial Properties of Vangueria madagascariensis J.F.Gmelin (Kirkir) Fruit
}

\author{
Abdel Moneim E. Sulieman ${ }^{1,2, *}$, Hamadanalla Abdelgadir ${ }^{2}$, Nawaf I. Alshammari ${ }^{1}$, Abdalbasit A. \\ Mariod $^{3,4}$, Abdel Muhsin A. Abdel Muhsin', Yazeed Albulaihed', Bandar Aloufi', Zakaria A. Salih ${ }^{2,5}$ \\ ${ }^{1}$ Department of Biology, Faculty of Science, University of Hail, Hail, KINGDOM OF SAUDI ARABIA. \\ ${ }^{2}$ Department of Food Engineering and Technology, Faculty of Engineering and Technology, University of Gezira, Wad-Medani, SUDAN. \\ ${ }^{3}$ Faculty of Science, University of Jeddah, Jeddah, KINGDOM OF SAUDI ARABIA. \\ ${ }^{4}$ Indigenous Knowledge and Heritage Center, Ghibaish College of Science \& Technology, Ghibaish, SUDAN. \\ ${ }^{5}$ Research and Training Station, King Faisal Univeristy, Alhassa, KINGDOM OF SAUDI ARABIA.
}

\begin{abstract}
Background: Vangueria madagascariensis fruits (Kirkir) produces compounds own various nutritional and medicinal properties. Objectives: The study purpose was to investigate the chemical composition and antioxidant properties of kirkir fruits (Vangueria madagascariensis). Materials and Methods: Proximate chemical composition, minerals and antioxidant properties of kirkir fruits were consucted via determination of total flavonoids, Ferric reducing antioxidant power (FRAP) and DPPH free radicals scavenging Assay. The Antimicrobial activity of plant extracts was also investigated. Results: The results of chemical properties indicated that kirkir fruit contained: moisture $6.96 \%$, protein $7.40 \%$, carbohydrates $59.85 \%$, fats $2.00 \%$, dietary fibers $17.50 \%$ and ash $3.10 \%$. It also contained micro nutritional elements such as ascorbic acid $(145.00 \mathrm{mg} / 100 \mathrm{~g})$ and beta-carotene $(102 \mathrm{lU} / 100 \mathrm{~g})$. The fruits were proved to be rich in phosphorus and potassium as 11.55 and $30.96 \mathrm{mg} / \mathrm{g}$, respectively. The antioxidant activity of methanolic extract was determined by DPPH and FRAP. The radical scavenging effect was observed with $\mathrm{IC}_{50}=36 \mu \mathrm{g} / \mathrm{ml}$ and $341 \mathrm{mM} \mathrm{TE} / \mathrm{g}$, respectively. The study showed that methanolic extract of kirkir fruit was proved to be effective as an antioxidant containing polyphenols $52.00 \mathrm{mg} \mathrm{GAE} / 100 \mathrm{~g}$ and flavonoids $7.25 \mathrm{mg} \mathrm{RE} / 100 \mathrm{~g}$. Conclusion: Kirkir fruit has showed its high nutritive value (macro nutritional elements, important micro nutritional elements such as ascorbic acid and beta-carotene and minerals of tested fruits. The extract of kirkir fruit was demonstrated to be effective as a an antimicrobial and antioxidant containing polyphenols and flavonoids. The study recommends isolation of active ingredients and development of novel drugs from the Vangueria madagascariensis plant.
\end{abstract}

Key words: Vangueria madagascariensis, Minerals, Polyphenols, Ascorbic acid, Radical scavenging effect, Methanolic extract.

\section{INTRODUCTION}

Vangueria is tripe of blooming plant in the Rubiaceae family which contains around 600 species in 25 genera. Vangueria madagascariensis a perpetual plant found in both amazingly hot living spaces, for example, the dry desert-like regions of the horn of Africa like Sudan, the downpour backwoods of tropical Africa and the southernmost piece of Madagascar., ${ }^{1,2}$ It belongs to the family Rubiaceae, it is a multipurpose wild fruit tree in western Sudan. A few species of genus Vangueria are broadly used in customary drug in different nations, example, in Tanzania, it is generally utilized for the redyment or potentially the executives of malaria, wounds, menstrual, and uterine issues. It is also utilized for the treatment of smallpox and bruises, herpes labialis, and in the administration of diabetes. $^{3-5}$
Submission Date: 20-09-2021; Revision Date: 26-11-2021; Accepted Date: 02-01-2022.

DOI: 10.5530/ijper.56.1s.40 Correspondence: Prof. Dr. Abdel Moneim E. Sulieman Department of Biology, Faculty of Science, Hail Univeristy, SAUDI ARABIA. E-mail: abuelhadi@hotmail. com

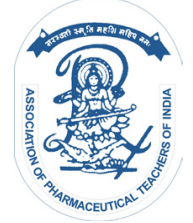

www.ijper.org 


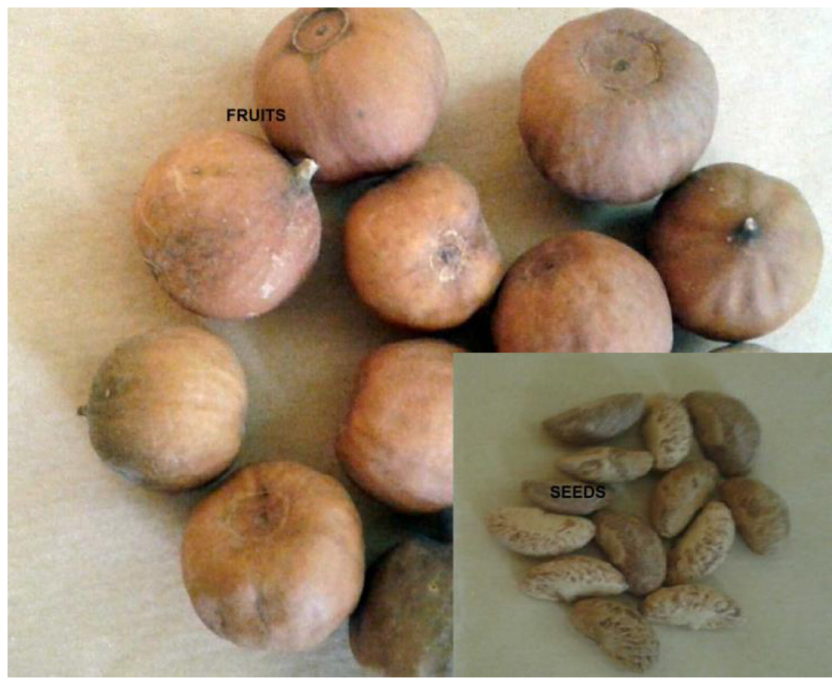

Figure 1: Vangueria madagascariensis dry fruits and seeds.

Each fruit of $V$. madagascariensis has 4 to 5 seeds, and the seed kernel (Figure 1) contains significant measure of oil which is higher than that of conventional oilseeds such as groundnut, cottonseed and sunflower. ${ }^{5}$ Some of the phytochemical components such as flavonoids identified from $V$. madagascariensis are known to have antiallergic, antiinflammatory, antimicrobial, antiproliferative, antioxidant, enzyme inhibition, and oestrogenic activities, synergism with antibiotics, and concealment of bacterial virulence. ${ }^{6-9}$

It has been reported that the antioxidant activities of flavonoids include extinguishing free radical elements, metal chelation, concealment of enzymes involved in free radical scavenging, and stimulationof enzymes that activate antioxidant activities. ${ }^{6}$ Research has additionally uncovered that food assets described by significant levels of flavonoids and related phenolic components may diminish the danger of cardiovascular sicknesses. ${ }^{10}$ This study aimed to determine the physicochemical properties of Vangueria madagascariensis J.F. Gmelin. Kirkir fruit and to determine its antioxidant activity using DPPH and FRAP methods.

\section{MATERIALS AND METHODS}

\section{Raw materials}

Vangueria madagascariensis (Kirkir) ripe fruits which had been originated and grown naturally in Zalengi, western Sudan, were purchased from Abougahal market in Elobaied city, Western Sudan, during seasons (2016-2017) and (2017-2018). The fruits were collected in clean plastic bags.

\section{Preparation of samples}

Samples were prepared as described by. ${ }^{11-13}$ The dirt, unripe fruits and extraneous matter were removed. Then fruit diameters was measured. In addition, the whole fruits, edible part, peel and a top loading balance weighed stones of fruits (model: D0001 - H R 120, A and D Company, Limited E C). The fruits were washed well with tap water to remove soil and dust particles, left in the shade to dry, and collected. Dry fruits were peeled, crushed to remove the seeds. Finely the edible part was collected and grinded (fine powder) by electric grinder(model-LM240-Groupe-SEB-53104, MayenneFrance), and kept tightly in a dark glass container at room temperature for further analysis.

\section{Physico-chemical analysis}

The physical properties of kirkir fruits were determined using standard methods. ${ }^{14}$ These variable included: the dimension (for 100 fruits) included length $(\mathrm{cm})$, width $(\mathrm{cm})$ and thickness $(\mathrm{cm})$, weight of 30 fruits $(\mathrm{g})$, percentage of seeds and peels.

The total extractable matter was estimated..$^{15}$ Calculated the content of extractable matter as following:

Total extractable matter $(\%)=\frac{\text { Volume of extract } \times \text { dried weight }}{25 \times \text { weight sample }} \times 100$

\section{Proximate composition estimation}

The contents of moisture, ash, crude fibre, crude fat, dietary fibre of kirkir ripe fruit were determined by method described. ${ }^{14}$ Carbohydrate contents were calculated as percentage by difference. The following formula is depicted in equation as shown below.

Carbohydrate $\%=100-(\%$ Moisture $+\%$ Protein + $\%$ Crude fibre $+\%$ Crude fat $+\%$ Ash content). ${ }^{14}$

\section{Caloric values}

The caloric values of the different samples were calculated by summing the values obtained through multiplying the contents of fats, protein and carbohydrates by the coefficients recorded bellow. ${ }^{16}$

$\begin{array}{ll}\text { Fat factor } & =8.37 \mathrm{~K} \mathrm{cal} / \mathrm{g} \\ \text { Protein factor } & =3.87 \\ \text { Carbohydrate factor } & =4.12 \\ 1 \mathrm{~K} \text { cal } & =4.184 \mathrm{KJ}\end{array}$

\section{Estimation of minerals content}

Mineral contents (calcium, sodium, iron, zinc, and potassium) of kirkir ripe fruit were determined by the use of Unicam 919 Atomic Absorption Spectrophotometer U.K following. ${ }^{14}$ official method. Test portions were 
dried and then ashed at $4500^{\circ} \mathrm{C}$ under a gradual increase (about $500^{\circ} \mathrm{C} / \mathrm{hr}$ ) in temperature. The ash was dissolved in $20 \mathrm{ml}$ of $1 \mathrm{~N} \mathrm{HCl}$ and heated for $5 \mathrm{~min}$ at $70^{\circ} \mathrm{C}$. The solute was then transferred quantitatively to a $100 \mathrm{ml}$ volumetric flask and made up to volume with distilled water. The absorbance of sample and standard solutions were determined. The standard curve plot of absorbance against the known concentration of standard solutions was used to determine the concentration of minerals in samples and expressed as shown in equation as shown in:

Mineral content $\mathrm{mg} / 100 \mathrm{~g}=\mathrm{R} \times$ Extract vol. $(\mathrm{L}) \times$

$$
\text { D.F } \times \mathrm{S}(\mathrm{Kg})
$$

Where:

$\mathrm{R}$ is mineral concentration in ppm $(\mathrm{mg} / \mathrm{Kg})$ as calculated using linear regression equation, D.F is Dilution Factor and $\mathrm{S}$ is sample weight $(\mathrm{Kg})$.

\section{Estimation of ascorbic acid}

Vitamin $C$ for kirkir ripe fruit was determined by 2,6 Dichlorophenol indophenols (DCIP) sodium salt method. ${ }^{17}$ Under this method, titration was performed in the presence of phosphoric acid/acetic acid solution, to maintain proper acidity ( $\mathrm{pH} \mathrm{1-3)} \mathrm{for} \mathrm{titration,} \mathrm{and} \mathrm{to}$ inhibit oxidation of the acid whereby $5 \mathrm{~g}$ of powdered edible part fruit sample were taken into $250 \mathrm{ml}$ erlenmeyer flask. $50 \mathrm{ml}$ of orthophosphoric acid were added to extract, to lower $\mathrm{pH}$ as well as to deproteinize the sample. The extracted samples were then filtered and titrated against standardized dichlorophenol indophenols until pink color which is the end point of the reduction process was observed. The volume of Dichlorophenol indophenols used was recorded and vitamin $\mathrm{C}$ content in samples was calculated according to the following equation:

$$
\mathrm{Mg} \text { of ascorbic acid }=(\mathrm{X}-\mathrm{B}) \times(\mathrm{F} / \mathrm{E}) \times(\mathrm{V} / \mathrm{Y})
$$

Where:

$\mathrm{X}$ is titre value, $\mathrm{B}$ is blank, $\mathrm{F}$ is $\mathrm{mg}$ of ascorbic acid equivalent to $1.0 \mathrm{ml}$ indophenols, $\mathrm{E}$ is number of $\mathrm{ml}$ assayed, $\mathrm{V}$ is initial assay solution volume and $\mathrm{Y}$ is volume of sample aliquot titrated.

\section{Polyphenols (Tannins content)}

Quantitative determination of tannins was carried out by using the modified vanillin- $\mathrm{HCl}$ colorimetric method as described. ${ }^{18}$ Tannins (polyphenols) after complexing with vanillin- $\mathrm{HCl}$ reagent give distinct colour proportional to their concentration. Thecolour intensity is then measured spectrophptometerically(model: Shimadzu - AA - 6800) at wavelength of $500 \mathrm{~nm}$ whereby the concentration of tannin is calculated.

A weight of $0.2 \mathrm{~g}$ sample was placed in a test tube. Then, $10 \mathrm{ml}$ of $1 \%$ vanillin/ $\mathrm{HCl} /$ methanol reagent were added. The test tube was capped and continuously shaken for $20 \mathrm{~min}$ and centrifuged (Fisher, USA) at 2500 $\mathrm{rpm}$ for $5 \mathrm{~min}$. The absorbency of the clear supernatant $(1.0 \mathrm{ml})$ was then measured spectrophptometerically (Milton Roy, USA) at a wavelength of $500 \mathrm{~nm}$ after incubation for $20 \mathrm{~min}$ at $30^{\circ} \mathrm{C}$. After that, the concentration of condensed tannins was determined and expressed as catechin equivalent (CE) from catechin standard curve prepared under the same conditions. For zero setting of the spectrophotometer, $1.0 \mathrm{ml}$-redistilled water was mixed with $5 \mathrm{ml}(4 \%) \mathrm{HCl} /$ methanol and $5 \mathrm{ml}$ vanillin in a test tube as a reference standard and the absorbency of the reference solution was adjusted to zero at $500 \mathrm{~nm}$.

\section{Calculation}

Catechin equivalent $(\mathrm{CE}) \%=\mathrm{C} \times \mathrm{V} \times 100 / \mathrm{W}$

Where:

$\mathrm{C}=$ Concentration corresponding to the optical density $\mathrm{V}=$ Volume of extract $(\mathrm{ml})$

$\mathrm{W}=$ Sample weight $(\mathrm{g})$.

\section{Total pectin}

Total pectin was estimated. ${ }^{17}$ Twenty-five $g$ of sample were mixed with $300 \mathrm{~mL}$ of $0.05 \%$ of the sodium salt of Ethylene Diamine Tetracetic Acid (EDTA), treated with $1.0 \mathrm{~N} \mathrm{NaOH}$ to reach a $\mathrm{pH}$ of 11.5 , allowed to sequester for $30 \mathrm{~min}$ at room temperature and the $\mathrm{pH}$ was adjusted to 5.0 with $1.0 \mathrm{~N}$ acetic acid. To this mixture, $0.1 \mathrm{~g}$ pectinase was added and stirred for about an $\mathrm{h}$, diluted to $500 \mathrm{ml}$ with distilled water, filtered through Whatman no. 1 and the first few $\mathrm{mL}$ of the filtrate were discarded. Two $\mathrm{mL}$ of the filtrate were diluted to $50 \mathrm{ml}$, from which $2 \mathrm{~mL}$ were taken for colorimetric determination of total pectin.

\section{Sugars determination}

Sugars in kirkir fruits powder were estimated by Lane and Eynon's method. ${ }^{19}$ In this method, reducing sugars and total sugars were estimated using Fehling solution, then non-reducing suagrs contentwas calculated as follows:

Non-reducing Sugars $(\%)=[$ Total Sugar $(\%)$ - Reducing Sugar $(\%)] \times 0.95$. 


\section{Antioxidant Properties of Vangueria madagascariensis (Kirkir) Fruit}

\section{Total phenolic content}

Total phenolic content was determined by ${ }^{20}$ method.

\section{Total flavonoid content}

Total flavonoid content was determined, ${ }^{20}$ where 0.5 $\mathrm{mL}$ aliquot of the extract solution was mixed with $2.0 \mathrm{ml}$ distilled water and subsequently with $\mathrm{NaNO}_{2}$ solution $(5 \%, 0.15 \mathrm{ml})$. After $6 \mathrm{~min}, \mathrm{AlCl}_{3}$ solution $(10 \%$, $0.15 \mathrm{~mL}$ ) was added and allowed to stand for $6 \mathrm{~min}$, thereafter, $\mathrm{NaOH}$ solution $(4 \%, 2.0 \mathrm{~mL})$ was added to the mixture. Immediately, distilled water was added to bring the final volume to $5.0 \mathrm{~mL}$. Then the mixture was properly mixed and allowed to stand for $15 \mathrm{~min}$. The intensity of pink colourwas measured at $510 \mathrm{~nm}$. The results were expressed as $\mathrm{mg}(+)$ - catechin equivalents (CEs) per g extract.

\section{(1-1) Diphenyl-2-picrylhydrazyl (DPPH) free radical scavenging assay}

The assay was carried out. ${ }^{21}$ Stock solutions of crude extracts and the positive control, ascorbic acid (400 $\mu \mathrm{g} / \mathrm{ml}$ ), were prepared in methanol at appropriate concentrations and added to DPPH $(200 \mu \mathrm{l}$ at100 $\mu \mathrm{m}$ prepared in methanol) in a 96 microlitre plate. The plate was then incubated for $30 \mathrm{~min}$ at $37^{\circ} \mathrm{C}$. Absorbance of each solution was measured at $517 \mathrm{~nm}$. The extract and standard were analyzed in triplicate at different concentrations and the $\mathrm{IC}_{50}$ values were determined as follows:

$\%$ Inhibition $=\frac{\text { absorbance blank sample }- \text { absorbance extract }}{\text { absorbance blank sample }} \times 100$

\section{Ferric reducing antioxidant power (FRAP) Assay}

The FRAP assay was determined. ${ }^{1}$ In this assay, the antioxidant activity is determined based on the ability to reduce ferric (III) to ferrous (II) iron. To perform this test, stock solutions which included acetate buffer (300 mm, pH 3.6), tripyridyltriazine (TPTZ) $(10 \mathrm{mM})$ solution in $\mathrm{HCl}(40(\mathrm{mM}) \mathrm{mmol} / \mathrm{L})$, and $\mathrm{FeCl}_{3} \cdot 6 \mathrm{H}_{2} \mathrm{O}$ solution $(20(\mathrm{mM}) \mathrm{mmol} / \mathrm{L})$ were used. The fresh working solution was prepared by mixing $25 \mathrm{~mL}$ acetate buffer, $2.5 \mathrm{~mL}$ TPTZ solution, and $2.5 \mathrm{~mL} \mathrm{FeCl}_{3} \cdot 6 \mathrm{H}_{2} \mathrm{O}$ solution and then equilibrating at $37^{\circ} \mathrm{C}$ for $15 \mathrm{~min}$ before using. Plant extracts $(0.15 \mathrm{~mL})$ at known concentrations were allowed to react with FRAP solution $(2.85 \mathrm{~mL})$ for $30 \mathrm{~min}$ in the dark. Analysis of extracts and positive control trolox $(200 \mathrm{mMmmol} / \mathrm{L})$ were done in triplicate. Readings of the Persian blue complex were then taken at
$593 \mathrm{~nm}$. Results were expressed in $\mathrm{mM}$ Trolox equivalent (TE)/g.

\section{Antimicrobial activity of plant extracts}

Dimethyl sulfoxide (DMSO) $(3 \% \mathrm{w} / \mathrm{v})$ was used to prepare the stock of water and ethanolic extract solutions to evaluate their activities against the standard pathogenic bacteria and fungi that used in this study. 200,400 and $600 \mathrm{mg} / \mathrm{ml}$ concentration of water and ethanolic extracts were used according to the, ${ }^{22}$ method. Ketoconazole antifungal and Gentamycin antibiotic were used as control.

\section{Statistical analysis}

Replicates of each sample were analyzed using Statistical Analysis System (SAS). The analysis of variance (ANOVA) and least significant difference (LSD at 5\%) were utilized to assess significant differences between means of samples.

\section{RESULTS AND DISCUSSION}

\section{Physical properties of Vangueria madgascariensis kirkir fruit}

The physical properties of kirkir fruits were carried out to determine the length, width and thickness, colour, weight of fruit, kernel and seed as percentage. Table 1 shows the dimensions of kirkir fruit for 100 fruits, from this Table the range was between 8.6 to $2.19 \mathrm{~cm}$ for length, this values were higher than the range of 2.03 to $1.05 \mathrm{~cm}$ for length that recorded, ${ }^{23}$ for the same fruit, 2.00 to $3.13 \mathrm{~cm}$ for width also this values were higher than the range of 2.22 to $0.92 \mathrm{~cm}$ for width, these values 3.60 to $2.23 \mathrm{~cm}$ for thickness wwere higher than the range of 2.23 to $0.90 \mathrm{~cm}$ for thickness, ${ }^{24}$ and 12.30 to $5.20 \mathrm{~g}$ for weight, these values were high than the range of 9.46 to $4.09 \mathrm{~g}$ for weight that obtained, ${ }^{23}$ for the same fruit.

The correlation coefficient between weight and length was week, and between weight and width was moderate, while between weight with thickness was strong. Table 1 shows the weight of 30 fruits, there were higher significant differences $(P \geq 0.05)$ in the weights. Large size11.399 $\mathrm{g}$ was reported as the higher weight, and small size $6.657 \mathrm{~g}$ showed as the lower weight. The means of those weights were higher than the values $9.46 \mathrm{~g}, 8.00 \mathrm{~g}$ that obtained, ${ }^{23,25}$ respectively.

Table 1 also shows the percentage of edible part (flesh) counted from the whole weight of the fruit, the results reported $3.8 \%$ for the large size fruit and $3.1 \%$ for the medium size fruit while only $2.0 \%$ for the small size fruit and that, these significant $(P \leq 0.05)$ differences in 


\begin{tabular}{|c|c|c|c|c|c|}
\hline \multirow{2}{*}{ Parameters } & \multicolumn{3}{|c|}{ Fruit size } & \multirow[t]{2}{*}{ LSD $_{0.05}$} & \multirow[t]{2}{*}{ SE \pm} \\
\hline & Small & Medium & Large & & \\
\hline Length $(\mathrm{cm})$ & 5.00 & 5.52 & 8.67 & 0.06013 & 0.01632 \\
\hline Width $(\mathrm{cm})$ & 4.50 & 5.75 & 6.22 & 0.1287 & 0.03510 \\
\hline Thickness $(\mathrm{cm})$ & 5.08 & 5.18 & 6.10 & 0.1060 & 0.03015 \\
\hline Weight (g) & 6.675 & 8.860 & 11.399 & 0.8987 & 0.4380 \\
\hline Edible part (flesh) (\%) & 2.0480 & 3.1150 & 3.8030 & 0.5885 & 0.2868 \\
\hline Seeds (\%) & 3.2530 & 4.0880 & 5.4060 & 0.5068 & 0.2470 \\
\hline Peels (\%) & 1.3660 & 1.6670 & 2.1460 & 0.3321 & 0.1619 \\
\hline Number of seeds & 2.0 & 4.0 & 5.0 & 0.6560 & 0.2261 \\
\hline
\end{tabular}

*Results are expressed as mean of three replicates.

\begin{tabular}{|c|c|}
\hline \multicolumn{2}{|c|}{$\begin{array}{c}\text { Table 2: Proximate composition of kirkir fruits } \\
\text { (on dry weight basis) and energy value. }{ }^{*}\end{array}$} \\
\hline Component & Percentage (\%) + SE \\
\hline Moisture & $6.95 \pm 0.01$ \\
\hline Crude protein & $7.40 \pm 0.02$ \\
\hline Fat & $2.00 \pm 0.08$ \\
\hline Fibre & $17.50 \pm 0.08$ \\
\hline Carbohydrate & $59.85 \pm 0.05$ \\
\hline Ash & $3.10 \pm 0.05$ \\
\hline Energy value (Kcal) & $291.9 \pm 0.05$ \\
\hline
\end{tabular}

* Results are expressed as mean \pm standard deviation of three replicates.

percentages of flesh were due to the differences in fruit weight. Table 1 also shows the percentage values for the fruit peels which reported $2.14 \%, 1.66 \%$ and $1.36 \%$ for large, medium and small size, respectively. There were no significant differences $(P \leq 0.05)$ between the fruits size. The large size fruits had seed $\%$ of $5.41 \%$, and medium size fruits had a seed $\%$ of $4.08 \%$ while the small size fruits had a $3.35 \%$, there were significant differences $(P<0.05)$ between the all sizes.

The number of seeds in small size fruit were only two seeds, and in medium size fruit were four while in large size were 5 seeds. The Figure of fruit was pale with bright-yellow-brown color in skin and edible part.

\section{Proximate composition of kirkir fruit}

Table 2 shows the percentage of moisture content obtained was $6.96 \%$, this value was slightly more than that reported Maroy (2018), ${ }^{26}$ who reported a value of $6.4 \%$, and less than that reported by Abdelrahaman et al. (2014), ${ }^{23}$ which was reported 7.92. Protein content of kirkir fruit was found to be $7.40 \%$. This value was in agreement with that reprted by Abdelrahaman et al. $(2014)^{24}$ which was $7.74 \%$, higher than than the value of $1.4 \%$ recorded by Ramalingum and Mahamoodally $(2014)^{1}$ and less than that reported by Mustafa, ${ }^{27}$ who reported a higher value $(22.2 \%)$. The changes of proteins however, indicate variations in metabolic activity during different development stages. ${ }^{24}$ The fat content value for kirkir fruit was found to be $2.0 \%$, this value was higher than $0.1 \%$ which was recorded by ${ }^{1}$ and similar to $2.35 \%$ that reported by Abdelrahaman et al. (2014). ${ }^{23}$

Table 2 also shows that the percentage of crude fibre content of kirkir fruit was $17.50 \%$. which was similar to $18.89 \%$ that reported by Abdelrahaman et al. (2014), ${ }^{23}$ and higher than $4.7 \%$ which, was recorded by Ramalingum and Mahamoodally (2014). ${ }^{1}$ This difference may be due to varieties. The ash content was found to be $3.10 \%$. This value was similar to 3.63 obtained by Abdelrahaman (2014), ${ }^{23}$ and for the same fruit, whereas lower than $4.90 \%$ recorded by Abdelmuti (2002), ${ }^{25}$ for the same fruit. The carbohydrate content of kirkir fruit as $59.85 \%$. This result was higher than $28 \%$ that obtained by Ramalingum and Mahamoodlly (2014), ${ }^{1}$ and close to $67.42 \%$ that was recorded by Abdelrahaman (2014). ${ }^{23}$ The energy value of kirkir as $291.9 \mathrm{kcal}$, this results is close to that reported by Abdelrahaman $(2014)^{24}$ and higher than $119.03 \mathrm{kcal}$ for the same fruit reported by Ramalingum and Mahamoodally (2014). ${ }^{1}$

\section{Physico-chemical properties of kirkir fruit}

Table 3 presents the physico-chemical properties of kirkir fruit, from the table, the total extractable matter of kirkir fruit was reported as $38.60 \mathrm{~g} / 100 \mathrm{~g}$ edible part, this result was close to $40.10 \mathrm{~g}$ recorded by Abdelrahaman. ${ }^{23}$ The $\mathrm{pH}$ value of kirkir fruit was 3.25 , this result was similar to 3.60 which was recorded by Abdelrahaman et al. ${ }^{24}$

The total phenols content (aqueous) of kirkir fruit was $1.95 \mathrm{mg} / \mathrm{g}$ as GAE, this result was found to be similar to $2.22 \mathrm{mg} / \mathrm{g}$ which was reported by Abdelrahaman et al. ${ }^{23}$ for the same fruit, whereas the (TPC-methanolic extract) of kirkir fruit was $52 \mathrm{mg} / \mathrm{g}$ as GAE, this value was lower than the range 112.5 to 170.4 that was recorded by Mustafa, ${ }^{27}$ and it was in close agreement with the range 


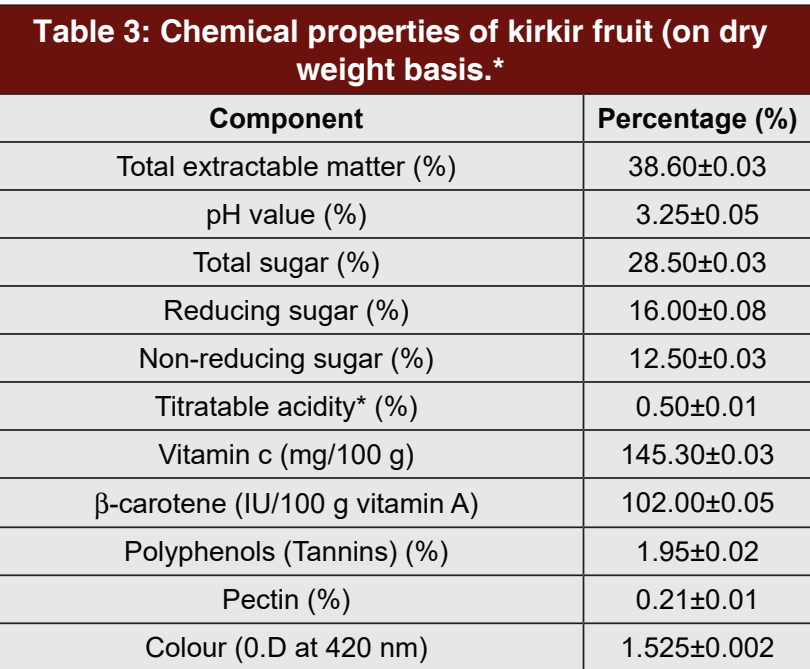

*Results are expressed as mean \pm standard deviation of three replicates.

(22.30-95.73 mg/g) for fourteen wild edible fruits from Burkina Faso recorded by Meda et al..$^{28}$ and lower than $61.22 \mathrm{mg} / \mathrm{g}$ for the same fruit reported by Ramalingum and Mahamoodally. ${ }^{1}$ Phenolic compounds are auxiliary metabolites, broadly circulated in plants. They are significant parts of numerous fruits and vegetables not only for their major influence on sensory qualities of the fruit (color, flavor, and taste), yet additionally for their antioxidant, anticarcinogenic, antimicrobial, antiallergic, antimutagenic, and mitigating properties.

Table 3 shows the total sugar of kirkir fruit was $28.50 \%$, reducing sugars were $16.00 \%$ and non-reducing sugars were $12.50 \%$. While the titratable acidity of kirkir was 0.50 , this finding agreed with the study carried out by Abdelrahaman et al. ${ }^{23}$ The ascorbic acid content obtained was $145 \mathrm{mg} / 100 \mathrm{~g}$. This value was higher than $4.7 \mathrm{mg} / 100 \mathrm{~g}$ that was reported by Ramalingum and Mahamoodally, ${ }^{1}$ and close to $169.69 \mathrm{mg} / 100 \mathrm{~g}$, that was reported by. ${ }^{23}$ The $\beta$-carotene content of kirkir fruit was $(102.00 \mathrm{I} \mathrm{U} / 100 \mathrm{~g})$, this result was close to 115.61 obtained by Abdelrahaman $e t$ al. ${ }^{24}$

Pectin is notable to be a significant component of the essentia cell wall and intracellular substance of higher plants. As a pervasive component of leafy foods, pectin is a characteristic component of the human diet and is considered as a constituent of dietary fibre due to be resistant in the human stomach and small intestine. ${ }^{29,30}$ Pectins have recently been appeared to have diverse biological activities, which may have a role in the beneficial effects of fruit and vegetable diets. In particular, pectins have been found to possess ROS scavenging activity which is known to rely upon the auxiliary features of pectin. ${ }^{31,32}$

\begin{tabular}{|c|c|}
\hline \multicolumn{2}{|c|}{ Table 4: Mineral composition of kirkir fruit $(\mathbf{m g} / \mathbf{g}){ }^{*}{ }^{*}$} \\
\hline Mineral & Value $(\mathbf{m g} / \mathbf{g})$ \\
\hline Calcium $(\mathrm{Ca})$ & $0.503 \pm 0.001$ \\
\hline Iron $(\mathrm{Fe})$ & $0.067 \pm 0.001$ \\
\hline Phosphour $(\mathrm{P})$ & $11.550 \pm 0.02$ \\
\hline Sodium $(\mathrm{Na})$ & $3.20 \pm 0.02$ \\
\hline Magnesium $(\mathrm{Mg})$ & $3.910 \pm 0.03$ \\
\hline Manganese $(\mathrm{Mn})$ & $0.196 \pm 0.001$ \\
\hline Potassium $(\mathrm{K})$ & $30.690 \pm 0.04$ \\
\hline
\end{tabular}

* Results are expressed as mean \pm standard deviation of three replicates.

Table 4 shows that the minerals content of kirkir fruit were Ca $0.67 \mathrm{mg} / \mathrm{g}$, Mn $0.196 \mathrm{mg} / \mathrm{g}, \mathrm{K} 30.690 \mathrm{mg} / \mathrm{g}$, Fe0.503, P11.550 and Magnesium 3.910.Abdelrahman, ${ }^{23}$ reported $\mathrm{Ca} 0.075$, Fe $0.522, \mathrm{P} 12.880, \mathrm{Na} 3.727, \mathrm{Mg}$ 4.369, Mn 0.028 and K 32.820 for the same fruit, Whereas Ramalingum and Mahamoodally, ${ }^{23}$ reported $\mathrm{Ca}$ $25.0 \mathrm{mg} / \mathrm{g}$, Fe 1.1.mg/g, Mn $39.0 \mathrm{mg} / \mathrm{g}$, P 366.0, K 521.0 and $\mathrm{Na} 28.0$ for the same fruit. While Muhammad et al..$^{33}$ found $\mathrm{Ca}$ 0.37, $\mathrm{Mg}$ 0.966, $\mathrm{Na} 2.03, \mathrm{~K} 1.21$, P 2.23, Fe $0.57, \mathrm{Mn} 0.02 \mathrm{mg} / \mathrm{g}$ for Gardenia aqualla (Gaudendutse) fruit. Mustafa et al. ${ }^{27}$ found that kirkir fruits had good quantities of protein and carbohydrtaes as well as appreciable amounts of macromierlas; $\mathrm{K}, \mathrm{Na}, \mathrm{Mg}$ and $\mathrm{Ca}$.

\section{Total flavonoids (TFC)}

The total flavonoids content was found as $7.95 \mathrm{mg}$ RE/g of the methanolic extract presented as mg of rutin equivalent/g of extract (Table 5), this result agreed with the findings of Ramalingum and Mahmoodally (2014). ${ }^{23}$ and lower than the range of 23-298.8 $\mathrm{mg} \mathrm{RE} / \mathrm{g}$ for the same plant (different parts) that recorded by Mustafa (2017). ${ }^{34}$

\section{Antioxidant Activities}

\section{DPPH free radicals scavenging Assay}

Results presented in Table 5 also shows the (DPPH) free radicals scavenging activity of the methanolic extract of kirkir fruit was $36 \mu \mathrm{g} / \mathrm{ml}$, this result was lower than $48.46 \mu \mathrm{g} / \mathrm{ml}$ for the same fruit that recorded by Ramalingum and Mahmoodally (2014), ${ }^{23}$ and within the range of $7.81-62.5 \mu \mathrm{g} / \mathrm{ml}$ for the same plant (different parts), that recorded by Mustafa et al. ${ }^{27}$

A free radical is characterizedas any atom or molecule having unpaired electrons. ${ }^{35}$ In living systems, free radicals are producedas a feature of the body's typical metabolic procedure. ${ }^{36}$ Antioxidants fight free radicals and protect us from various diseases.

\section{Ferric reducing antioxidant power (FRAP)}

Results presented in Table 5 shows that the ferric reducing antioxidant power (FRAP) of the methanolic 
Table 5: Total phenolic content, Total flavonoid content, DPPH and FRAP of kirkir fruit extract.

\begin{tabular}{|c|c|c|}
\hline Sample & Tests & Result (a mount) \\
\hline $\begin{array}{c}\text { Methanolic extract of ripe fruit of kirkir } \\
\text { (pericarp) }\end{array}$ & Total phenolic content (TPC) & 52 (mg GAE/g of ripe fruit) \\
\cline { 2 - 3 } & Total flavonoid content (TFC) & $7.95(\mathrm{mg} \mathrm{RE} / \mathrm{g}$ of ripe fruit) \\
\cline { 2 - 3 } & DPPH & $36\left(\mathrm{IC}{ }_{50}\right)(\mu \mathrm{g} / \mathrm{mL})$ \\
\cline { 2 - 3 } & FRAP & $341(\mathrm{mM}) \mathrm{mmol} / \mathrm{Ltorolx} \mathrm{equivalent} \mathrm{(TE)/g} \mathrm{ripe} \mathrm{fruit}$ \\
\hline
\end{tabular}

\begin{tabular}{|c|c|c|}
\hline Tested micro-organisms & Sample & Control \\
\hline Fungi & Kirkir fruit methoanlic Extract & Ketoconazole \\
\hline Aspergillus fumigatus (RCMB 002008) & 20 & 17 \\
\hline Aspergillus niger (RCMB 002005) & 10 & 15 \\
\hline Candida albicans RCMB 005003 (1) ATCC 10231 & 13 & 20 \\
\hline Gram Positive Bacteria & & Gentamycin \\
\hline Staphylococcus aureus (RCMB010010) & 11 & 24 \\
\hline Bacillus subtilis RCMB 015 (1) NRRL B-543 & 08 & 26 \\
\hline Staphylococcus epidermidis RCMB 009 (2) & 13 & 28 \\
\hline Gram Negatvie Bacteria & & Gentamycin \\
\hline Escherichia coli (RCMB 010052) ATCC 25955 & 13 & 30 \\
\hline $\begin{array}{l}\text { Salmonella typhimurium } \\
\text { RCMB } 006 \text { (1) ATCC } 140281{ }^{\prime} 1 ` 12\end{array}$ & 09 & 17 \\
\hline Proteus vulgaris RCMB 004 (1) ATCC 13315 & 10 & 25 \\
\hline
\end{tabular}

Mean zone of inhibition in mm beyond well diameter $(6 \mathrm{~mm})$ produced on a range of pathogenic microorganisms. Results are depicted in the following Table above: The test was done using the diffusion agar technique, Well diameter:6.o mm (100 $\mu \mathrm{l}$ was tested), RCMB: Regional Center for Mycology and Biotechnology.

extract of kirkir fruit was reported in this study as $341 \mathrm{mM}$ (TE)/g, this value was lower than 357.08 $\mathrm{mM}$ (TE)/g which was recorded by Ramalingum and Mahmoodly. ${ }^{23}$

\section{Antimicrobial activity of plant extracts}

Results presented in Table 6 shows the reaction of the methanolic extract used of $20 \mathrm{mg} / \mathrm{ml}$ against a number of fungi and bacterial species. This extract showed higher inhibitory zone $(20 \mathrm{~mm})$ against Aspergillus fumigatus (RCMB 002008) compared to Ketoconazole antifungal with an inhibitory zone of $17 \mathrm{~mm}$. In conrast Ketoconazole showed higher efficacy with inhibition zones of $15 \mathrm{~mm}$ and $20 \mathrm{~mm}$, respectively against Aspergillus niger (RCMB 002005) and Candida albicans (RCMB 005003 (1) ATCC 10231) compared to methanolic extract of kirkir fruit which showed inhibition zones of $10 \mathrm{~mm}$ and $13 \mathrm{~mm}$, respectively.

On the other hand, gentamycin showed stronger reaction against the tested gram $(+)$ bacteria Staphylococcus aureus (RCMB010010), Bacillus subtilis RCMB 015 (1) NRRL B-543 and Staphylococcus epidermidis RCMB 009 (2) with inhibition zones of 24, 26 and $28 \mathrm{~mm}$, respectively, compared to methanolic extract of kirkir fruit which showed inhibition zones of $11,8 \mathrm{~mm}$ and $13 \mathrm{~mm}$,respectively (Table 6).
Gentamycin showed stronger reaction against the tested gram (-) bacteria Escherichia coli (RCMB 010052) ATCC 25955, Salmonella typhimurium RCMB 006 (1) ATCC 14028 and Proteus vulgaris RCMB 004 (1) ATCC 13315) with inhibition zones of 30,17 and $25 \mathrm{~mm}$, respectively, compared to methanolic extract of kirkir fruit which showed inhibition zones of 13, 9 and $10 \mathrm{~mm}$, respectively. Results conducted revealed that methanolic extract of kirkir fruit have antifungal and antibacterial activity against the tested microorganisms.

\section{CONCLUSION}

In conclusion, the chemical properties of kirkir fruit has showed its high nutritive value (macro nutritional elements, important micro nutritional elements such as ascorbic acid and beta-carotene and minerals of tested fruits. It was proved to be rich in phosphorus and potassium. The study showed that methanolic extract of kirkir fruit was demonstrated to be effective as a an antioxidant containing polyphenols and flavonoids, very effective as a an antifungal and antibacterial. In addaition, kirkir has a DPPH radical scavenging with great power. In order to utilize these phenolic compounds as antioxidants, it is advisable to substitute methanol solvent with other solvents with low toxicity. Further studies are needed to isolate and purify active 
ingredients and development of novel drugs from the Vangueria madagascariensis plant.

\section{ACKNOWLEDGEMENT}

Authors are thankful to the Ministry of Higher Education and Scientific Research of the Sudan for the financial support. Authors also want to extend their deep gratitude to the Staff and technicians of the Departments of Food Engineering, University of Gezira for their assistance.

\section{CONFLICT OF INTEREST}

The authors declare no conflict of interest.

\section{ABBREVIATIONS}

TFC: Total flavonoid content; DPPH: Diphenyl-2picrylhydrazyl; FRAP: Ferric reducing antioxidant power; SAS: Statistical Analysis System (SAS); ANOVA: Analysis of Variance.

\section{Author contributions}

A. E. Sulieman, A. A. Mariod,-- developed the concept and designed the experiment; H.Abdelgair - collected data and performed analyses; A. E. Sulieman, A. A. Mariod, N. Alshammari -A. Abdel Muhsin, Z. Salih analysed the data and wrote the paper.

\section{REFERENCES}

1. Mahomoodally F. Vangueria madagascariensis JF Gmelin (Rubiaceae) - an under-utilised African traditional medicinal food plant with potential applications. J Intercult Ethnopharmacol. 2014;3(1). doi: 10.5455/ jice.20131209015917.

2. Oshi MMA. Studies on the propagation of Vangueria madagascariensis Gmel. Journal of Agricultural Science and Food Research. 2020;5:2020.

3. Gurib-Fakim A, Brendler T. Medicinal and aromatic plants of Indian Oceanislands: Madagascar, Comoros, Seychelles and Mascarenes, Medpharm, Stuttgart, Germany; 2004. doi: 10.1021/jm040147.

4. De Boer HJ, Kool A, Broberg AW, Mziray WR, Hedberg I, Levenfors JJ. Antifungal and anti-bacterial activity of some herbal remedies from Tanzania. J Ethnopharmacol. 2005;96(3):461-9. doi: 10.1016/j.jep.2004.09.035, PMID 15619565.

5. Musa KH, Abdullah A, Jusoh K, Subramaniam V. Antioxidant activity of pinkflesh guava (Psidium guajava L.): effect of extraction techniques and solvents. Food Anal Methods. 2011;4(1):100-7. doi: 10.1007/s12161-010-9139-3.

6. Pereira DM, Valentão P, Pereira J, Andrade P. Phenolics: From chemistrytobiology. Molecules. 2009;14(6):2202-11. doi: 10.3390/molecules14062202.

7. Cushnie TPT, Lamb AJ. Recent advances in understanding the antibacterial properties of flavonoids. Int J Antimicrob Agents. 2011;38(2):99-107. doi: 10.1016/j.jjantimicag.2011.02.014, PMID 21514796.

8. Procházková D, Bousová I, Wilhelmová N. Antioxidant and prooxidant properties of flavonoids. Fitoterapia. 2011;82(4):513-23. doi: 10.1016/j. fitote.2011.01.018, PMID 21277359.

9. Roleira FM, Tavares-da-Silva EJ, Varela CL, Costa SC, Silva T, Garrido J, et al. Plant derived and dietary phenolic antioxidants: Anticancer properties. Food Chem. 2015;183:235-58. doi: 10.1016/j.foodchem.2015.03.039, PMID 25863633.
10. Kabera JN, Semnana E, Mussa ER, et al. Plant secondary metabolites: Biosynthesis, classification, function and pharmacological properties. J Pharm Pharmacol. 2014;2(7):377-92.

11. Mushumbus DG. 2015. Production and characterization of jackfruit jam. A dissertation Submitted in Partial Fulfilment of the Requirements for the Degree of Master of Science in Food. Scie. Of SOKOINE University of Agric. Morogoro, Tanzania [cited 16/12/2021]. Available from: https://www. semanticscholar.org/paper/PRODUCTION-AND-CHARACTERIZATION-OFJACKFRUIT-JAM-A/460e82ce3aba436ab00dd8a41f878d9c575d1917.

12. Rhman $H$, lqbal $T$, Farhan $T$, Javed $M T$, Saeed $R$, Khalid $S Q$, et al. Elemental assessment of fruits and vegetables. J Pharm Res. 2014;8(4):597-600.

13. Jasiem TM, Almugdadi SFH, Aljubory IS, Latef QN. Phytochemical Study and antibacterial activity of Crude alkaloids and Mucilage of Cordia myxain Iraq. Int J Pharm Sci Rev Res. 2016;39(1):232-6.

14. AOAC. Official methods of analysis. $16^{\text {th }}$ ed. Washington: Association of Analytical Chemists; 1995. DOI DC. doi: 10.12691/ajfn-3-6-1.

15. WHO/FAO. Preparation and use of food-based dietary Guidelines. Report of a joint https://www.who.int/nutrition/publications/nutrientrequirements/ WHO_TRS_880/en/; 1996.

16. IMNA. Institute of Medicine of the National Academies. The National Academies Press. Dietary Reference Intakes for Energy, carbohydrate, Fiber, fat, Fatty Acids, cholesterol, Protein and Amino Acids. Washington, DC; 2002. doi: 10.17226/10490.

17. AOAC. USA: Association of Analytical Chemists. International Publishers: 2000. Official methods of analysis of A.O.A.C. International. $17^{\text {th }}$ ed [cited 16/12/2021]. Available from: https://www.worldcat.org/title/official-methodsof-analysis-of-aoac-international/oclc/44761301.

18. Price ML, Butler LG, Rogler JC, Featherston WR. Overcoming the nutritionally harmful effects of tannin in sorghum grain by treatment with inexpensive chemicals. J Agric Food Chem. 1979;27(2):441-5. doi: 10.1021/jf60222a052.

19. Ranaganna S. New Delhi, India. (CF. T.R.I), Mysore. Tata, McGraw Hill Publishing Company limited; 1995. Manual analysis of fruit and vegetable products [cited 16/12/2021]. Available from: https://agris.fao.org/agrissearch/search.do?recordID=US201300540990.

20. Phuyal N, Jha PK, Raturi PP, Rajbhandary S. Total phenolic, flavonoid contents, and antioxidant activities of fruit, seed, and barkextracts of Zanthoxylum armatum DC. Scientific World Journal. 2020;2020:Article ID8780704. doi: 10.1155/2020/8780704, PMID 32256249.

21. Alsaleem KA, Elfaruk MS, Hammam ARA. Estimation of antioxidants activity and capacity to capture free radical using 2, 2-diphenyl-1-picrylhydrazyl (DPPH) assay. Aust J Basic Appl Sci. 2020;14(11):86-93. doi: 10.22587/ ajbas.2020.14.11.9.

22. Fadeyi A, Raheem R, Bello M, Njan A, Olatunji L, Afolabi S, et al. Antibacterial activity of the crude extracts of Moringa. Nig. J Pharm Sci. 2015;14(1):35-42.

23. Abdelrahman NA, Awad II, Elrakha EB. Characterization of some Sudanese edible forest fruits. J agric-food Appl. Sci. 2014;2(2):39-44.

24. Salwa MAR, Sawsan AAE, Sahar FD, Ashraf AK. Antibacterial activity of some wild medicinal plants collected from western Mediterranean coast, Egypt: Natural alternatives for infectious disease treatment. Afr J Biotechnol. 2011;10(52):10733-43. doi: 10.5897/AJB11.007.

25. Abdel Muti OMS. Nutritive value of wild plants of the Sudan. Arab. J Food Nutr. 2002;3(3):6-67.

26. Mead B, Gurnow RW. Statistical methods in agriculture experimental biology. London, New York: Chapman and Hall; 1983. doi: 10.1201/9780203738559.

27. Mustafa SE, Mohamed RA, Mariod AA. Vangueria madagascariensis: Phytochemical constituents, bioactive compounds, traditional and medicinal uses. Wild Fruits Compos. 2019. Nutritional Value and Products:157-64.

28. Lamien-Meda A, Lamien CE, Compaoré MM, Meda RN, Kiendrebeogo M, Zeba B, et al. Polyphenol content and antioxidant activity of fourteen wild edible fruits from Burkina Faso. Molecules. 2008;13(3):581-94. doi: 10.3390/ molecules13030581, PMID 18463567.

29. Lattimer JM, Haub MD. Effects of dietary fiber and its components on metabolic health. Nutrients. 2010;2(12):1266-89. doi: 10.3390/nu2121266, PMID 22254008.

30. Venzon SS, Canteri MH, Granato D, Junior BD, Maciel GM, Stafussa AP, et al. Physicochemical properties of modified citrus pectins extracted from 
orange pomace. J Food Sci Technol. 2015;52(7):4102-12. doi: 10.1007/ s13197-014-1419-2, PMID 26139875.

31. Wang W, Ma XP, Jiang P, Hu L, Zhi Z, Chen J, et al. Characterization of pectin from grapefruit peel: A comparison of ultrasound-assisted and conventional heating extractions. Food Hydrocoll. 2016;61:730-9. doi: 10.1016/j. foodhyd.2016.06.019.

32. Maroyi A. Vangueria madagascariensis Fruit Tree: Nutritional, Phytochemical Pharmacological, and Primary health care applications as Herbal Medicine [review]. Scientifica (Cairo). 2018;2018:Article ID 4596450. doi: 10.1155/2018/4596450, PMID 30515346.
33. Muhammad A, Dangoggo SM, Tsafe AI, Itodo AU, Atiku FA. Proximate, Minerals and Anti-nutritional Factors of Gardenia aqualla (Gauden dutse) Fruit Pulp. Pak J Nutr. 2011;10(6):577-81. doi: 10.3923/pjn.2011.577.581.

34. Mustafa ASE. The potential of Vangueria madagascariensis as a source for un-conventional oil in Sudan, Agricultural and Biological Sciences [journal:2017:3], 4. 2017;28-32.

35. Umameswari M, Chatterjee TK. In vitro antioxidant activities of the fractions of Coccinia grandis L. leaf extract. Afr J Tradit Complement Altern Med. 2008;5:61-73.

36. Saha MR, Alam MA, Akter R, Jahangir R. In vitro free radical scavenging activity of Ixora coccinea L Bangladesh J Pharmacol. 2008;3(2):90-6. doi: 10.3329/bjp.v3i2.838.

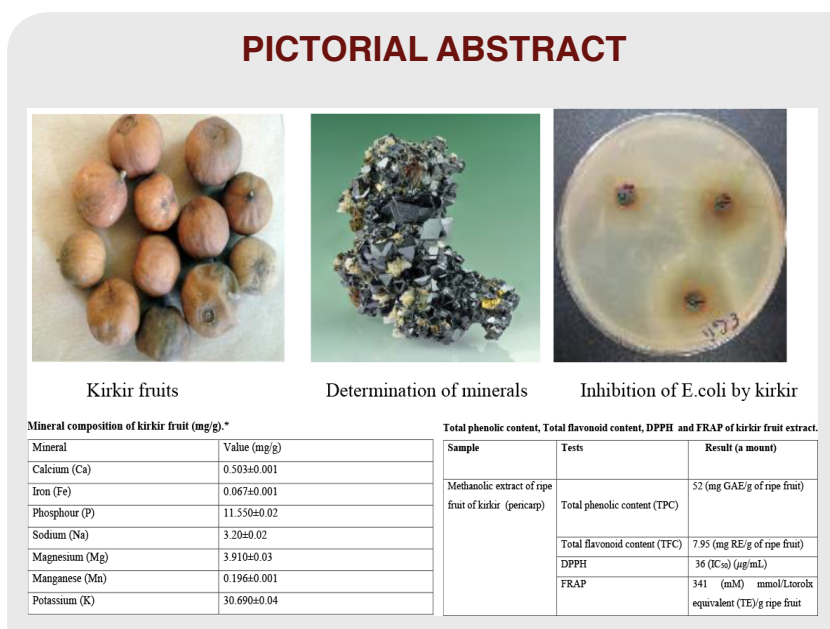

\section{SUMMARY}

Vangueria madagascariensis fruits (Kirkir) is reported for its various nutritional and medicinal properties. Chemical methods as well as well antimicrobial activity of the plant fruit were carried out. The results of chemical properties indicated that kirkir fruit contained: moisture $6.96 \%$, protein $7.40 \%$, carbohydrates $59.85 \%$, fats $2.00 \%$, dietary fibers $17.50 \%$ and ash $3.10 \%$. It also contained micro nutritional elements such as ascorbic acid $(145.00 \mathrm{mg} / 100 \mathrm{~g})$ and betacarotene (102 IU/100 g). The fruits were proved to be rich in phosphorus and potassium as 11.55 and $30.96 \mathrm{mg} / \mathrm{g}$, respectively. The antioxidant activity of methanolic extract was determined by DPPH and FRAP. The radical scavenging effect was observed with $\mathrm{IC}_{50}=$ $36 \mu \mathrm{g} / \mathrm{ml}$ and $341 \mathrm{mM} \mathrm{TE} / \mathrm{g}$, respectively. The study showed that methanolic extract of kirkir fruit was proved to be effective as an antioxidant containing polyphenols $52.00 \mathrm{mg}$ GAE/100 $\mathrm{g}$ and flavonoids $7.25 \mathrm{mg} \mathrm{RE} / 100 \mathrm{~g}$. The study recommends isolation of active ingredients and development of novel drugs from the Vangueria madagascariensis plant.

Cite this article: Sulieman AE, Abdelgadir H, Alshammari I. Mariod A, Abdel Muhsin A, Albulaihed Y, et al. Chemical Composition, Antioxidant and Antimicrobial Properties of Vangueria madagascariensis J.F.Gmelin (Kirkir) Fruit. Indian J of Pharmaceutical Education and Research. 2022;56(1s):s32-s40. 